Review

\title{
Bioremediation Methods for the Recovery of Lead-Contaminated Soils: A Review
}

\author{
Monica Rigoletto, Paola Calza, Elisa Gaggero *, Mery Malandrino $\mathbb{D}$ and Debora Fabbri $\mathbb{D}$ \\ Department of Analytical Chemistry, University of Torino, Via Pietro Giuria 5, 10125 Torino, Italy; \\ monica.rigoletto@edu.unito.it (M.R.); paola.calza@unito.it (P.C.); mery.malandrino@unito.it (M.M.); \\ debora.fabbri@unito.it (D.F.) \\ * Correspondence: elisa.gaggero@edu.unito.it
}

Received: 30 April 2020; Accepted: 18 May 2020; Published: 20 May 2020

\begin{abstract}
Currently, the pollution of soils by heavy metals is a problem of paramount relevance and requires the development of proper remediation techniques. In particular, lead is a frequently detected soil contaminant that poses adverse effects to the environment and human health. In this review, we provide an overview of the bioremediation treatments promoted by plants (phytoremediation), fungi, or bacteria that could be applied to areas polluted by lead. These restoration processes have the advantage of being environmentally friendly and cost-effective solutions that exploit plants to immobilize and extract contaminants from soil and water, and fungi and bacteria to degrade them. Phytoremediation is an extensively studied and mature practice, with many in-the-field applications where numerous plant species have been employed. In contrast, bioremediation processes promoted by fungi and bacteria are very promising but, up to now, studies have been mostly performed at a laboratory scale with only a few implementations in real-world situations; therefore, further research is needed.
\end{abstract}

Keywords: contaminated soil; lead pollution; phytoremediation; biosorption; biomineralization

\section{Introduction}

Lead is one of the major contaminants present in soil on a global scale [1,2], and numerous studies have pointed out its harmful effects on the environment and human health. Its occurrence in the environment is due to mineral rock weathering and anthropogenic sources, with the latter including the extraction and melting of metals, the combustion of coal, industrial activities, atmospheric deposition, agriculture, and waste disposal [3]. The production of arsenate-based insecticides, batteries, pigments, and fertilizers [4,5] contributes significantly to the lead pollution of soils. On the other hand, atmospheric deposition is closely related to past use of tetraethyl lead (TEL) as an additive in gasoline [5] and to fuel combustion to produce heat and electricity [6].

Lead is present in soil in various forms, characterized by different mobility, toxicity, and bioavailability. Metal bioavailability accounts for the amount of element available for absorption by living organisms such as humans, animals, and plants [7] and is strictly connected to the metal chemical form. In turn, its chemical form in soil is affected by numerous processes, e.g., precipitation and dissolution, ion exchange, absorption and desorption, complexation, immobilization and biological mobilization, and absorption by plants. Lead is frequently detected in soil as ionic lead (e.g., $\mathrm{Pb}$ (II) in the form of $\mathrm{PbSO}_{4}$ ), oxides and hydroxides, and lead-metal oxyanion complexes [8]. Phosphates, carbonates (at $\mathrm{pH}$ above 6), hydroxides/oxides, sulfides, and pyromorphites are some of the most stable and insoluble forms in which lead occurs in soils in a wide range of $\mathrm{pH}$ values $[9,10]$.

In view of the widespread lead pollution and the threat posed to the environment and human health, there is growing attention on the recovery or reduction of its concentration in soils. This review 
aims to focus on the different bioremediation strategies applied so far and will consider various studies concerning both the use of plants for phytoremediation and the exploitation of fungi and bacteria for the removal or stabilization of lead in the soil. Indeed, several processes have been extensively studied in recent years, with the aim of replacing traditional chemical and physical methods and implementing the use of environmentally friendly techniques to restore soils.

\section{Lead Toxic Effects}

Lead toxic effects on human health are linked to lead's capability to interfere with many enzymes and to bind biologically important molecules. The damage can involve a large number of organs, affecting the hematopoietic, gastrointestinal, kidney, muscle, neurological, reproductive, and genetic systems [11]. Children are more vulnerable than adults because of the frequency of pica and hand-to-mouth activity coupled with a higher rate of intestinal absorption and retention [12]. The severity of the adverse effects on human health depends both on the dose and on the length of the exposure to lead, which can occur by inhalation or through the consumption of polluted water, vegetables, and animals farmed in soils rich in this heavy metal [13].

For these reasons, the assessment of the adsorption capacity by vegetables and fruits growing in lead polluted soils and destined for human consumption is of great relevance, especially considering the increasing development of horticulture in urban areas more exposed to anthropic pollution sources.

Lead is not essential for plants. It has no nutritional or biological function, but it is conveyed in plant tissues through foliar uptake, being trapped by the cuticular wax and then diffused into the leaf tissue [14] or moving through the roots and crossing the root-cell plasma membrane. In the last case, a possible transport pathway of $\mathrm{Pb}$ appears to be the plasma membrane cation channels, such as Ca-channels $[15,16]$. Then, $\mathrm{Pb}$ retention in the roots is based on the binding of metal to ion-exchangeable sites placed on the cell wall and on extracellular precipitation, mainly in the form of $\mathrm{Pb}$ carbonate deposited on the cell wall [17]. Inside plants, lead causes an increased production of reactive oxygen species (ROS), with the consequent damage to cellular lipid membranes with a resultant alteration of the photosynthetic processes [18].

Abdul Qados [19] established that high concentrations of lead affect the dry weight of roots and shoots: in general, as a common response to stress posed by heavy metals, the above-ground biomass is strongly reduced, causing growth inhibition. This can be related to a reduction in meristematic cells and to the inhibition of the proton pump responsible for the cells' elongation process [20]. Likewise, earlier studies showed that $\mathrm{Pb}$ could bind to nucleic acids, resulting in an inhibition of cell division and plant growth.

The exposure to $\mathrm{Pb}$ negatively affects several important plant stress indicators, such as (1) the composition of free amino acids and other nitrogen compounds, (2) the relative water content (RWC), and (3) the chlorophyll yield. High concentrations of the metal reduce the action of enzymes involved in chlorophyll pigments biosynthesis, with a consequent decrease in the photosynthetic potential and in plant growth [20], and a reduction of RWC, probably due to stomatal closure.

In addition, the potential hazard to human health of edible species grown in the $\mathrm{Pb}$-contaminated soils is linked not only to the initial concentration of lead in the soil, but also to the relationship between the $\mathrm{Pb}$ concentration in soil and plants that depends on soil chemical and physical properties $(\mathrm{pH}$, phosphorus content, organic matter, cation exchange capacity, texture) and crop age and species [21,22]. Finster et al. [23] noted that lead content in soil and roots are well correlated, whereas the correspondence is generally less predictable in the case of leaves and edible parts. This can be justified considering the contribution of air pollution: the deposition of dust containing the metal can be responsible for most of the contamination of broad-leaved plants [21]. Conversely, McBride et al. highlighted that $\mathrm{Pb}$ content in vegetables (lettuce, carrots, beans, and tomatoes) grown in soils with a detected lead amount equal to $400 \mathrm{mg} / \mathrm{kg}$ did not exceed the limits settled for the metal by international health standards (European Union has set the limit at $0.1 \mathrm{mg} / \mathrm{kg}$ f.w. for fruits and roots and at $0.3 \mathrm{mg} / \mathrm{kg}$ f.w. for leafy greens) [21]. Indeed, each vegetable has a specific uptake capability and a different 
translocation factor to the edible parts. Herbs show the highest levels, whereas fruits present the lowest, even if their overall contribution to human intake is greater than for other species [24]. As for leafy and root vegetables, there is a higher uptake of metals for the former, especially in the case of lettuce and spinach [25-28]. As an example, tomatoes show a scarce accumulation capability, while turnips and carrots accumulate moderate lead concentrations [21,22]. The uptake ability is influenced by $\mathrm{pH}$, and the lead absorption in lettuce and carrots increases at low $\mathrm{pH}$ values $(<6)[21]$.

Safety of vegetables destined for human consumption cannot therefore always be guaranteed, even after a careful washing before consumption. A recent study analyzed how the type of washing solution of vegetable samples can influence the residual $\mathrm{Pb}$ concentration and proved that even the addition of a detergent to washing water does not guarantee a significant decrease in the lead content [23].

Amendments are frequently added in soils to improve their quality, and this practice can provide different and somehow opposite effects. It can render lead more soluble and therefore more available [22], but, in contrast, it can reduce the bioavailability of lead through its immobilization into insoluble lead compounds as observed with the employment of phosphate compounds [29].

\section{Phytoremediation}

Phytoremediation is an in-situ restoration process that uses plants to transform, immobilize, and extract contaminants, such as heavy metals, from soils or water. Plants exhibit a very efficient mechanism to uptake nutrients present at low concentrations in the soil through their roots using different strategies to solubilize micronutrients, such as the production of chelating agents or by inducing a $\mathrm{pH}$ modification. The capability for metals uptake into the growing plant's tissues is estimated through the bioconcentration factor $(\mathrm{BF})$, defined as:

$$
\mathrm{BF}=\mathrm{C}_{\mathrm{p}} / \mathrm{C}_{\mathrm{so}}
$$

where $C_{p}$ is the metal concentration in the plant and $C_{s o}$ is the metal concentration in the soil [30-32].

Plants are also capable of storing and translocating elements that are not essential but have chemical properties similar to those of nutrients. The translocation factor (TF) is used to evaluate metal transport and can be calculated as:

$$
\mathrm{TF}=\mathrm{C}_{\mathrm{s}} / \mathrm{C}_{\mathrm{r}}
$$

where $C_{s}$ and $C_{r}$ are the metal concentrations in the aerial parts and roots, respectively [31-34]. A TF $>1$ indicates that the plant translocates metals from the root to the shoot, while with a TF $<1$ the metals are preferentially accumulated by immobilization in roots. According to Subhashini et al. [30], phytoremediation approaches can be classified on the basis of the mechanism involved in the pollutant removal (Figure 1), which are as follows:

(1) phytoextraction, when contaminants are concentrated from soil to plant tissues;

(2) phytodegradation, if plants are able to degrade organic contaminants;

(3) rhizofiltration, when exploiting the capability of plant's roots to remove pollutants from contaminated water, adsorbing them into the extracellular negatively-charged residues present on the outer coatings of the roots and absorbing them through membrane proteins that act as carrier molecules [35];

(4) phytostabilization, when plant's roots are able to reduce the bioavailability of contaminants in the soil;

(5) phytovolatilization by obtaining the pollutants' volatilization. 


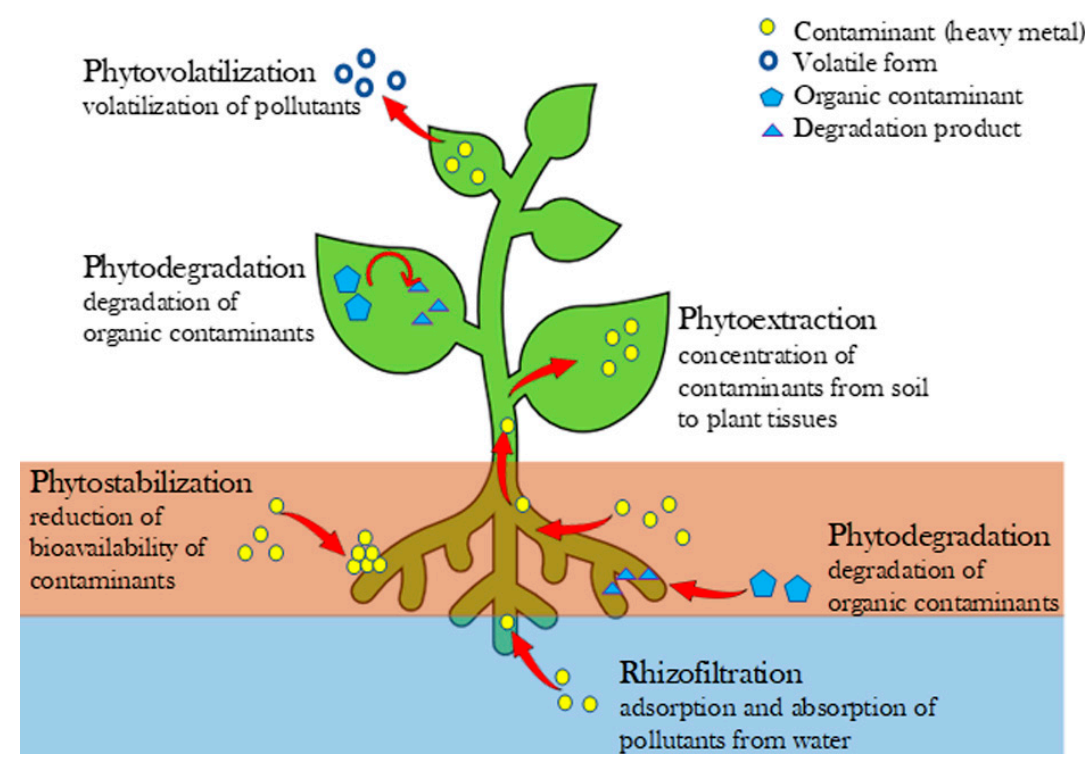

Figure 1. Schematic representation of different phytoremediation approaches by plants under study.

The success of phytoremediation depends on the plant's ability to store large quantities of metals in its tissues and to accumulate biomass rapidly, without being negatively affected by the metals. Taking into account that the tolerance to high concentrations of heavy metals depends on the type of plant, the study of stress indicators is crucial for the selection of the best candidate for phytoremediation.

Baker [36] classified the different plant-soil relationships into three types:

(a) accumulators that concentrate metals in above-ground tissues;

(b) indicators that regulate uptake and transport of metals so that the internal concentration reflects the external concentration;

(c) excluders for which an accumulation of heavy metals occurs in the roots, but the entry and transport in the aerial parts is limited [32].

Plants with $\mathrm{BF}>1$ and TF $>1$ are more suitable for phytoextraction as the aerial parts are easily eliminated by harvesting, whereas plants with $\mathrm{BF}>1$ and $\mathrm{TF}<1$ are more appropriate for phytostabilization.

\subsection{Phytoremediation Capability of Spontaneously Grown Plants}

Recently, several plants and conditions have been explored to restore lead-contaminated mining areas in different countries via phytoremediation processes [31,37]. Lago-Vila et al. [31] studied Cytisus scoparius for the phytoremediation of Spolic Technosols in a Rubiais mine. Four areas were selected, and three topsoil samples were collected in each zone. The bioavailable fraction of $\mathrm{Pb}$ in the mine's soils was assessed by 14 different single extractions using three groups of extractants (Table 1):

(a) diluted solution of strong acids $\left(\mathrm{HCl}\right.$ and $\left.\mathrm{HNO}_{3}\right)$, acetic acid, and acidified $\mathrm{CaCl}_{2}$;

(b) chelating agent solutions (EDTA and DTPA), mix of low molecular weight organic acids, (LMWOAs), and neutral salt solution $\left(\mathrm{MgCl}_{2}\right)$;

(c) neutral salt solutions and bidistilled water (BDW). 
Table 1. Reagents used for the extraction of the bioavailable fraction of $\mathrm{Pb}$ in the soil.

\begin{tabular}{|c|c|c|}
\hline Category & Extractant & Conditions \\
\hline Bidistilled water & BDW & - \\
\hline \multirow{7}{*}{ Neutral salt solutions } & $\mathrm{Ca}\left(\mathrm{NO}_{3}\right)_{2}$ & $0.1 \mathrm{M}$ \\
\hline & $\mathrm{MgCl}_{2}$ & $1 \mathrm{M}$ \\
\hline & $\mathrm{NH}_{4} \mathrm{NO}_{3}$ & $1 \mathrm{M}$ \\
\hline & $\mathrm{NaNO}_{3}$ & $0.1 \mathrm{M}$ \\
\hline & $\mathrm{Mg}\left(\mathrm{NO}_{3}\right)_{2}$ & $0.5 \mathrm{M}$ \\
\hline & $\mathrm{CaCl}_{2}\left(\right.$ no ac) ${ }^{*}$ & $0.01 \mathrm{M}$ \\
\hline & $\mathrm{CaCl}_{2}(\mathrm{ac})^{* *}$ & $0.01 \mathrm{M}$ with $\mathrm{HCl}(0.1 \mathrm{M})$ \\
\hline \multirow[t]{2}{*}{ Organic acids } & $\begin{array}{l}\text { LMWOA (low molecular weight } \\
\text { organic acids) }\end{array}$ & $\begin{array}{c}\text { acetic, lactic, citric, malic, and } \\
\text { formic acids (ratio } 4: 2: 1: 1: 1 \text { ) } \\
\text { solution with a total concentration } \\
\text { of } 10 \mathrm{mM}\end{array}$ \\
\hline & HOAc & $0.11 \mathrm{M}$ \\
\hline \multirow[t]{2}{*}{ Chelating agents } & EDTA & $\begin{array}{l}\mathrm{Na}_{2} \text {-EDTA } 0.01 \mathrm{M}+ \\
\mathrm{CH}_{3} \mathrm{COONH}_{4} 1 \mathrm{M}\end{array}$ \\
\hline & DTPA & $\begin{array}{c}0.005 \mathrm{M} \text { DTPA + } 0.1 \mathrm{M} \text { TEA + } 0.01 \\
\mathrm{M} \mathrm{CaCl}_{2}\end{array}$ \\
\hline \multirow{2}{*}{ Diluted acids } & $\mathrm{HCl}$ & $0.1 \mathrm{M}$ \\
\hline & $\mathrm{HNO}_{3}$ & $0.5 \mathrm{M}$ \\
\hline
\end{tabular}

${ }^{*}$ no ac: not acidified; ** ac: acidified.

Ten types of $C$. scoparius, grown spontaneously in the soil, were harvested in the same locations of soil sampling; then, the roots and aerial part were separated and dried at $60{ }^{\circ} \mathrm{C}$ until reaching a constant weight. The $\mathrm{Pb}$ content in the plants' aerial parts and roots was obtained by extraction with $\mathrm{H}_{2} \mathrm{O}_{2}$ and $\mathrm{HNO}_{3}$ (1.5:9 v:v) in a microwave oven followed by ICP-OES analysis. Results showed that C. scoparius accumulated and concentrated $\mathrm{Pb}$ mainly in roots, having $\mathrm{TF}<1$ and $\mathrm{BF}>1$, so acting as a lead phytostabilizer. However, a value of BF greater than 1 was obtained only if the neutral salts and LMWOAs are used as extractants. Moreover, even if LMWOAs are good predictors of metal bioavailability for phytoextraction techniques, as they are according to Lago-Vila et al. [31] and other studies [38,39], the statistical analysis in this study evidenced that the concentrations in the soil detected after extraction with different extractants were not correlated with the concentrations observed in the different parts of the plants, so suggesting that their use could not be suitable to assess the bioavailability of $\mathrm{Pb}$ in these contaminated soils.

Rotkittikhun et al. [37] used a similar approach for the restoration of a lead mine located in Bo Ngam (Thailand), contaminated with cerussite $\left(\mathrm{PbCO}_{3}\right)$, by spontaneously grown plants. Soil was collected from five points located at the surface $(0-10 \mathrm{~cm})$, subsurface $(10-40 \mathrm{~cm})$, and around the plant roots. After collection and drying at $60{ }^{\circ} \mathrm{C}$ for $48 \mathrm{~h}$, soil samples were reduced into a fine powder, digested with $\mathrm{HNO}_{3}$, and $\mathrm{Pb}$ concentration was determined by flame atomic absorption spectrophotometer (F-AAS). A sequential extraction method was used to measure the extractable lead in soil: firstly, $\mathrm{Ca}\left(\mathrm{NO}_{3}\right)_{2}$ was used to extract the exchangeable fraction and then the acid-soluble fraction was extracted by acetic acid. Concomitantly, plants grown spontaneously in the soil were taken from the same site of the soil samples.

Forty-eight species ( 22 herbs, 17 grasses, 5 undershrubs, 2 shrubs, and 2 climbers) were collected. After collection, washing, separation into shoots and roots, and drying, plant samples were digested with $\mathrm{HNO}_{3}$ and analyzed by F-AAS. Results showed that twelve species behaved as accumulators 
(TF $>1$ or shoot/root quotient $>1$ ) and 36 as excluders $(\mathrm{TF}<1$ or shoot/root quotient $<1)$; most of these (fourteen species) belonged to the grass family (Poaceae).

Eleven plant species belonging to seven different families were classified as hyperaccumulators on the basis of three criteria: (1) accumulation in shoots 10-500 times more than usual plants (lead $5 \mathrm{mg} / \mathrm{kg}$ ), (2) shoot accumulation $>1000 \mathrm{mg} / \mathrm{kg}$, and (3) shoot $/$ root quotient $>1$. Among these, three herbs (S. arvensis, Co. sumatrensis, and Cyperus sp.) and two shrubs (C. odoratum and B. asiatica) could be considered as possible phytoremediators for lead-contaminated soil. This can justify their observed broad presence in lead-contaminated sites supported by high propagation rates. C. odoratum and B. asiatica can reach the height of $34 \mathrm{~m}$ and are perennial shrubs, generally preferable in phytoremediation treatment, preventing the need for annual planting.

\subsection{Phytoremediation Capability of Plants in Spiked Soils}

Many phytoremediation studies [40-42] were performed under controlled experimental conditions in soils spiked with lead solutions or powder to assess the restoration capacity of selected plants. For this purpose, Alaboudi et al. [43] investigated the phytoextraction ability of sunflower, in particular Helianthus annuus species, to remove lead and cadmium from soil. An air-dried loamy sandy soil was collected from Burnley campus garden (Melbourne University, Australia) and mixed 1:1 (v/v) with perlite. Seeds of sunflower were sown on this mixed soil and, after two weeks, they were treated with solutions containing different concentrations of lead aimed to evaluate the effect of an increasing level of pollutant exposure on plant growth. Total content of lead was measured by AAS after digestion with aqua regia and a mixture of $\mathrm{HCl} / \mathrm{HNO}_{3}$ (for soil and plant's shoots and roots, respectively). Growth and biomass production dropped owing to the high concentrations of $\mathrm{Pb}$. $\mathrm{Pb}$ content in roots increased more than in shoot as metal concentration in the soil rose. However, H. annuus exhibited a BF $<1$ and so cannot be considered an accumulator.

Catharanthus roseus was studied by Subhashini et al. [30] for lead and nickel phytoremediation. Again, plants were grown in pots filled with garden soil watered with metals solutions and the uptake was estimated after 20 days. After harvesting, washing, and drying, plants were digested with a mixture of $\mathrm{HCl} / \mathrm{HNO}_{3}$ and metals content was analyzed in AAS. Results showed that $C$. roseus behaves as a lead accumulator in roots $(\mathrm{BF}>1$ and $\mathrm{TF}<1)$ and is therefore useful for phytostabilization treatments.

Compared to grasses and other smaller plants, trees have the advantage of having deeper roots that allow them to reach deeper layers of soil. Within this framework, Abdul Qados [19] studied the appropriateness of three trees (Acacia saligna, Eucalyptus rostrate, and Conocarpus erectus) for phytoremediation. Three-month-old seedlings were transplanted in plastic pots containing soil mixed with a fine powder of $\mathrm{PbCl}_{2}$. Roots of the tree species seemed to be more resistant to heavy metal pollution than shoots, since the above-ground biomass was strongly reduced after treatment with a high concentration of metal. A. saligna was the most tolerant, as no significant alterations of the plant biomass were observed. Among the stress indicators, the lowest RWC was reported for A. saligna shoots and roots, while the chlorophyll pigments did not seem to undergo alterations.

Both A. saligna and E. rostrata accumulated $\mathrm{Pb}$ mainly in roots $(\mathrm{TF}<1)$, while $C$. erectus did so mainly in shoots (TF $>1$ ). Moreover $A$. saligna showed a metal content in its biomass higher than that of the other two plants. Although higher concentrations of lead were found in roots of A. saligna and E. rostrata, significantly high concentrations were also measured in the above-ground tissues; these, together with absence of reduction in the biomass, support these plants as possible $\mathrm{Pb}$ hyperaccumulators.

\subsection{In Field Phytoremediation}

Phytoremediation is an in-situ restoration process, so the application of this technique in the field by planting suitable species has gained importance. Gurajala et al. [44] led an in-the-field field experiment on a farm in Quzhou, China. The soil was polluted by heavy metals owing to a previous intensive use of agricultural chemicals, fertilizers, and irrigation with contaminated canal water, and the 
total concentration of $\mathrm{Pb}$ was $123.66 \pm 0.84 \mathrm{mg} / \mathrm{kg}$. The authors compared the phytoextraction efficiency of eighty different types of Brassica juncea L. (Indian mustard), the oldest cultivated crop in this area, by sowing and growing the plants in the contaminated soil. The plants were harvested at 90 days maturity, dried, and then digested with an $\mathrm{HNO}_{3}: \mathrm{HClO}_{4}$ mixture. The total content of heavy metals in plant samples were determined using an inductively coupled plasma mass spectrometer (ICP-MS). In general, although the average uptake in shoots was higher than roots, TF greatly varied among the 80 Indian mustard cultivars, of which 57 genotypes exhibited TF $>1$ for $\mathrm{Pb}$. In particular, genotypes IM-24 and IM-32 accumulated more Pb, proving to be the most efficient varieties for in-the-field phytoremediation among the studied genotypes.

A summary of the considered phytoremediation studies is reported in Table 2.

Table 2. Summary table of phytoremediation studies carried out in Pb-contaminated soils.

\begin{tabular}{|c|c|c|c|}
\hline & Study & Plant Species & Results \\
\hline \multirow[t]{2}{*}{$\begin{array}{l}\text { Phytoremediation } \\
\text { capability of } \\
\text { spontaneously grown } \\
\text { plants }\end{array}$} & Lago-Vila et al. [31] & C. scoparius & $\begin{array}{c}\text { Accumulated and } \\
\text { concentrated } \mathrm{Pb} \text { mainly in } \\
\text { roots, so acting as a lead } \\
\text { phytostabilizer }(\mathrm{TF}<1, \mathrm{BF}>1)\end{array}$ \\
\hline & Rotkittikhun et al. [37] & $\begin{array}{l}\text { Herbs: } \\
\text { S. arvensis } \\
\text { Co. sumatrensis } \\
\text { Cyperus sp. } \\
\text { Shrubs: } \\
\text { C. odoratum } \\
\text { B. asiatica }\end{array}$ & $\begin{array}{l}\text { Hyperaccumulators: } \\
\text { accumulation in shoots } 10-500 \\
\text { times more than usual plants } \\
\text { (lead } 5 \mathrm{mg} / \mathrm{kg} \text { ) } \\
\text { shoot accumulation }>1000 \\
\mathrm{mg} / \mathrm{kg} \text { shoot/root quotient }>1 \text {, } \\
\text { Perennial shrubs are preferable }\end{array}$ \\
\hline \multirow[t]{4}{*}{$\begin{array}{l}\text { Phytoremediation } \\
\text { capability of plants in } \\
\text { spiked soils }\end{array}$} & Alaboudi et al. [43] & H. annuus (sunflower) & $\begin{array}{l}\mathrm{BF}<1 \text {, so cannot be } \\
\text { considered an accumulator but } \\
\text { an excluder }\end{array}$ \\
\hline & Subhashini et al. [30] & C. roseus & $\begin{array}{l}\text { Accumulator }(\mathrm{BF}>1 \text { and } \\
\mathrm{TF}<1 \text { in roots) so it is useful } \\
\text { for phytostabilization }\end{array}$ \\
\hline & \multirow[t]{2}{*}{ Abdul Qados [19] } & Trees: C. erectus & $\begin{array}{l}\text { Accumulated } \mathrm{Pb} \text { mainly } \\
\text { in shoots }\end{array}$ \\
\hline & & E. rostrata, A. saligna & $\begin{array}{l}\text { Possible hyperaccumulators } \\
\text { (high concentrations in the } \\
\text { above-ground tissues, no } \\
\text { reduction of biomass) }\end{array}$ \\
\hline $\begin{array}{c}\text { In-the-field } \\
\text { phytoremediation }\end{array}$ & Gurajala et al. [44] & $\begin{array}{l}\text { B. juncea L. (Indian } \\
\text { mustard), } 80 \text { types }\end{array}$ & $\begin{array}{l}\text { Genotypes IM- } 24 \text { and IM-32 } \\
\text { had } \mathrm{TF}>1 \text { and accumulated } \\
\text { more } \mathrm{Pb} \text { than other varieties }\end{array}$ \\
\hline
\end{tabular}

\subsection{Limitation and Disadvantages of Phytoremediation}

Phytoremediation is an environmentally friendly method applicable to a wide range of contaminants with many advantages, such as being aesthetically pleasing, socially acceptable, and low in cost [45]. Nevertheless, it also has some drawbacks as it can be a time-consuming process; it may take up to several years to remediate a contaminated site, making this technique unsuitable for restoring areas that may constitute an acute risk for human beings and the ecosystem [45-47].

Another significant limitation of this approach consists in the necessary contact between the contaminants and the root zone of plants. Thus, the central role played by roots in phytoremediation has generally limited its application to shallow, contaminated soils (one meter deep at most) $[45,46,48,49]$, with the only exception being the use of some trees employed to reach target zones in the range of one to several meters [47]. Additionally, the age of plants greatly affects their physiological activity; indeed, the ability to absorb ions is greater for the roots of younger plants. Though, the larger biomass of an older plant may balance its lower physiological activity [48]. 
Another constraining factor is the maximum level of contaminants that can be accumulated by plants, which limits their use to sites with low metals content. This level was rated for hyperaccumulators, on a dry weight basis, to vary from about $0.2 \%$ for more toxic elements $(\mathrm{Cd}, \mathrm{Pb})$ to above $2 \%$ for the less toxic ones $(\mathrm{Zn}, \mathrm{Ni}, \mathrm{Cu})[50]$.

Climatic and hydrologic conditions affect plant growth as well, and the United States Environmental Protection Agency (US-EPA) recognized the following factors and effects as important [51]:

- soil preparation time, period of planting, and need for irrigation depend on the frequency and intensity of rainfall as well as snowmelt;

- fluctuations in air temperature that influence plants growth performance and are affected in turn by sunlight;

- natural (vegetation) or artificial (neighboring buildings) shading that can modify plants developing capability;

- the growing season length must be taken into account in the forecast of necessary times for recovery since phytoremediation processes are more likely to be active during this period;

- wind affects evaporation and can damage plants with dispersion of volatiles substances and debris;

- $\quad$ all the factors described above are influenced by regional and local weather patterns.

During the planning of remediation activities, all these factors must be taken into account (though these factors cannot be predicted with certainty, and their effects cannot always be controlled) together with the surface water drainage and runoff, which affect the water content and temperature of soil, and with the possibility that the introduction of non-native species may affect biodiversity [46].

Metal uptake by plants also depends on the metal's bioavailability. When metals are bound to the soil, factors such as $\mathrm{pH}$, redox potential, and organic matter content will affect the ionic and plant-available forms in which the contaminants are present. In particular, bioavailability of heavy metals in soils decreases above $\mathrm{pH} 5.5-6$ and increases if chelating agents and micronutrients are added [52]. Agronomic techniques such as addition of nutrients, organic matter, or other kind of amendments can cause modifications in soil such as changes to $\mathrm{pH}$, oxygen content, and other soil characteristics [47].

\subsection{Phytoremediation By-Products}

The fate of harvested plants used in phytoremediation presents a challenge, since the nature of phytoaccumulated contaminants may be classified as hazardous and requires an adequate final disposal [46]. In phytoremediation practice, the production and disposal of biomass must also be assessed in the planning phase. A possible solution could be a holistic approach that allows using the phytoremediation waste as a different type of raw material, as suggested by Witters et al. [53].

The choice of the suitable biomass recovery technique depends on the type of plant and the content of the contaminants. Several treatments have been proposed [54] and comprise direct combustion with energy production, biofuel production, and materials production. Traditionally, the most employed system for the recovery of stored biomass energy is direct combustion, whose final products are fumes and ashes. Fumes are properly treated before being released into the atmosphere; instead, ashes are generally landfilled or, in some cases, treated to recover metals. In direct combustion processes, the metals can affect chemical reactions and induce catalytic phenomena, accumulating at the end of process in fly ash and settling on the walls of the chimneys.

Another kind of thermal conversion is gasification, which comprises four phases: drying, pyrolysis, reduction, and combustion. Gasification treatment seems to be particularly suitable for the recovery of phytoremediation by-products because high temperature degrades organic contaminants and other problematic elements are removed with the ashes [54]. This treatment produces syngas, which is then used as an energy source, basic substance for chemical industry, or for hydrogen production. 
Pyrolysis is also a stand-alone treatment that decomposes material under anaerobic conditions and has no emissions to the air. In this case, the final products are pyrolytic fluid oil and coke, which could be used in smelters as suggested by Bridgwater et al. [55]

Biomass can also be digested anaerobically and converted to digestate and biogas [56]. Biogas can then be burned in a gas engine for the production of electricity, with heat recovery in a combined heat and power (CHP) system, or purified to produce biomethane.

According to Mudhoo et al. [57] and Witters et al. [53], during the fermentation and anaerobic digestion processes, the presence of heavy metals at concentrations above certain thresholds can inhibit biochemical reactions and cause toxic effects on microorganisms. This type of recovery strategy is affected by many factors such as the solubility of the metal and the type of microorganisms involved [57]. After the anaerobic digestion process. metals concentrate in the digestate [58], so precluding its use as a soil amendment.

Oil plants can be mechanically pressed to obtain pure plant oil (PPO), transformed into biodiesel through transesterification, and used as biofuel. PPO has a slightly lower calorific value (PCI) than diesel [59]. Even if in these plants metals are concentrated less in seeds than in leaves, fruits, and branches [60], there are no data on the possible effects of metals on the biodiesel production process. So, further studies are required to better understand the possible presence of metals in the fumes derived from the combustion of so-obtained biodiesel [52].

Biomass can also be used to obtain different types of materials: matches and wooden packaging (produced from trees and vegetable textile fibers, when employing herbaceous plants or shrubs), bioplastics, or biochar [54].

\section{Bioremediation via Fungi and Bacteria}

Bioremediation via fungi and bacteria is defined by Leung [61] "as the transformation or degradation of contaminants into less dangerous or non-dangerous chemical products". This technology uses microorganisms to reduce, eliminate, contain, or transform pollutants present in soils, sediments, water, and air. The efficiency of the process depends on various factors, such as:

(a) the concentration and bioavailability of the contaminants;

(b) the characteristics of the treated site (e.g., $\mathrm{pH}$, the redox potential, and the oxygen content);

(c) availability of nutrients;

(d) humidity;

(e) temperature (it influences the metabolism of microorganisms) [62].

In this framework, biostimulation and bioaugmentation are the most widely used bioremediation strategies. The former is defined by Margesin et al. [63] as a type of natural remediation that takes advantage by optimizing site conditions such as aeration, $\mathrm{pH}$, and temperature or by adding organic or inorganic nutrients to improve the pollutants' degradation. On the other hand, bioaugmentation consists of the addition of microbial cultures pre-grown in the laboratory to support the native microbial populations of a site, so promoting the degradation of contaminants. Indigenous or native microbes are generally present in very small quantities and may not be efficient to abate the contaminant; therefore, bioaugmentation represents a path to provide specific microbes in sufficient numbers to complete biodegradation [64]. These methods are mainly used for the removal of organic contaminants, especially for the degradation of Polycyclic Aromatic Hydrocarbons (PAHs) [65-67], but microorganisms can also be used effectively in the treatment of soils contaminated by metals.

\subsection{Bioremediation by Fungi}

As stated in Section 3.1, lead bioavailability is strictly connected to its dangerousness towards living organisms. Microorganisms existing in the soil are deeply involved in lead speciation through processes as varied as biosorption, intracellular accumulation, biomineralization, and chelation with 
self-produced organic acids (Figure 2). All these pathways can be exploited to increase (or decrease) the bioavailability of lead through its mobilization (or immobilization) [68].

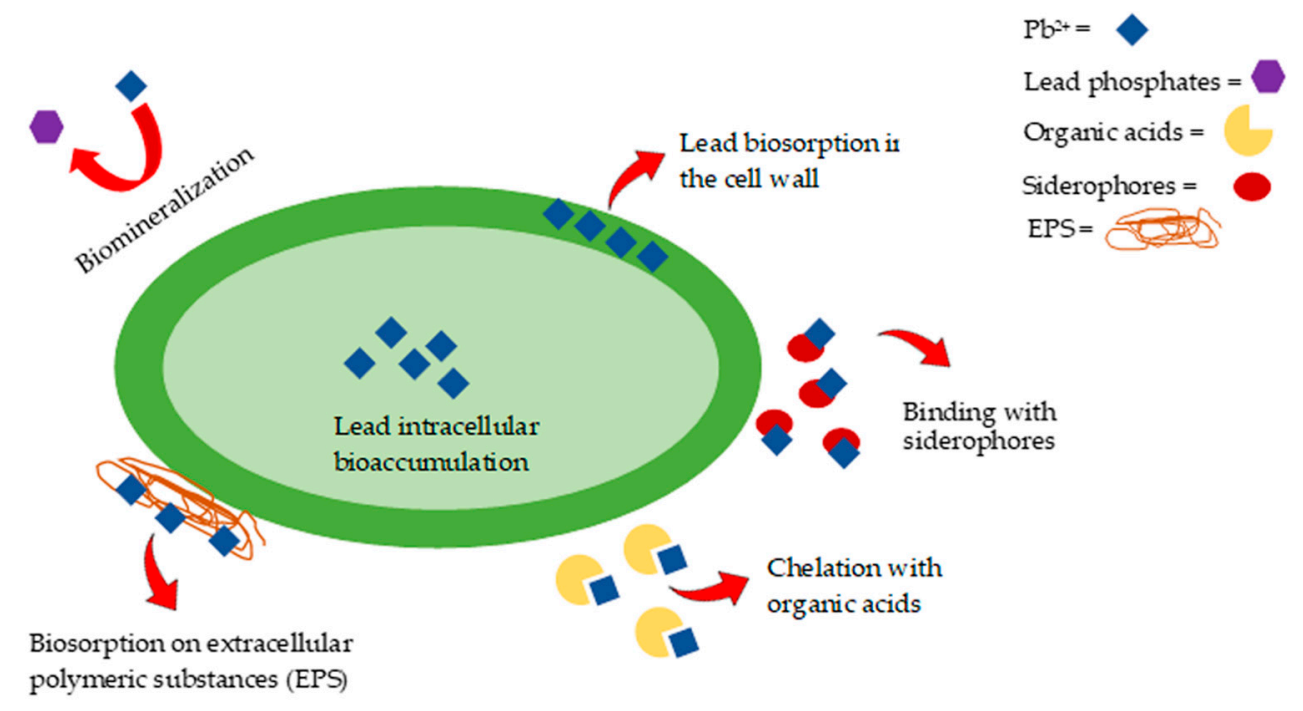

Figure 2. Schematic representation of the principal mechanisms involved in bioremediation of lead by fungi and bacteria.

Rhee et al. [69] identified two fungi, Paecilomyces javanicus and Metarhizium anisopliae, isolated from a former lead mining area in Scotland and capable of transforming metallic lead into chloropyromorphite. They incubated lead shots in the presence and absence of fungi and verified that the metabolites produced by the fungi, in particular organic acids, contributed to the release of mobile lead species, which subsequently precipitated as pyromorphite. Energy-dispersive X-ray analysis (EDXA) and X-ray powder diffraction analysis (XRPD) confirmed that, in soils treated with fungi, phosphorus and chlorine were also present in addition to the main elements found in abiotic conditions (namely lead, carbon, and oxygen); furthermore, $\mathrm{X}$-ray mapping allowed for the identification of the position of phosphorus and chlorine and confirmation of the formation of chloropyromorphite as the main product.

Povedano-Priego et al. [68] studied biomineralization (the process by which living forms influence the precipitation of mineral materials [70]) of lead phosphate by fungal strains isolated from decaying woods. In their work, they assessed the tolerance of three different fungi, Asperigillum niger, Penicillium chrysogenum, and Trichoderma viride, to $\mathrm{Pb}$ (II) by testing the minimum inhibitory concentration (MIC, lowest concentration of metal in which no visible fungal growth occurs). A. niger and P. chrysogenum showed resistance to high concentrations of lead with MICs $>8 \mathrm{mM}$. The authors also evaluated the lead phosphate formation after incubation of P. chrysogenum with lead shot. Environmental scanning electron microscopy (ESEM) showed the precipitation of lead phosphate mineral, while the analysis by high resolution transmission electron microscopy (HRTEM) confirmed the deposition of lead mineral phases on fungi cell walls. This may be related to the enhancement of the biosorption process by the fungus in response to the stress conditions caused by the presence of lead.

Thirty-six microorganisms (fungi and yeasts) were isolated from contaminated soil in Morocco [71]. Among them, Asperigillus and Penicillium strains proved to be the most tolerant of heavy metals, capable of growing with high concentrations of metals (MIC between 20 and $25 \mathrm{mM}$ for $\mathrm{Pb}$ ), and as such they are interesting candidates for the bioremediation of lead-contaminated soils.

The behaviors of Asperigillus niger, Penicillium bilaiae, and a Penicillium sp. in lead-polluted soils characterized by scarce or rich nutrient content were studied by Arwidsson et al. [72]. In particular, fungal response was studied in terms of production of exudates such as low molecular weight organic acids (LMWOAs). It is well known that in the presence of heavy metals fungi produce organic acids 
with complexing capacities, so inducing the immobilization of metals through their bonds to fungal cell walls and the formation of soluble metal complexes. During the study [72], the latter phenomenon was investigated by evaluating the possible use of chelating agents produced by the fungal strains to mobilize the lead and subsequently extract it to operate a bioremediation on the soil. The organic acids exuded from fungi were mainly oxalic acid and citric acid; the maximum concentration of LMWOAs was in the range of 60 to $80 \mathrm{mM}$ with a corresponding decrease of $\mathrm{pH}$ to values between 2 and $4 \mathrm{mM}$ for A. niger and 15 and $20 \mathrm{mM}$ for P. bilaiae with a corresponding $\mathrm{pH}$ of 3.5-4. The production by Penicillium sp. gave concentrations below $1 \mathrm{mM}$ and $\mathrm{pH}$ generally above 6.5 regardless of the presence of nutrients.

The production of LMWOAs led to the mobilization of lead from the soil, especially in the presence of nutrients, up to a maximum release of $12 \%$ of $\mathrm{Pb}$ after 5 days. The production of chelating agents, especially citric acid, combined with the consequent decrease in $\mathrm{pH}$, produced an enhanced release of lead from the soil.

The biosorption capacity of $A$. niger for lead present in high concentrations in a heavy-metals-contaminated soil in an Indian peri-urban agricultural area was investigated by varying $\mathrm{pH}$ and temperature. The fungal strain showed the maximum absorption efficiency toward $\mathrm{Pb}(21.5 \%)$ in the $\mathrm{pH}$ range 4 to 5.4 ; the absorption capability was lowered at higher $\mathrm{pH}$ values, probably due to an accumulation of metal ions inside intrafibrillar capillaries of the cell walls or inside cells following a microprecipitation mechanism. In regard to the temperature effect, $A$. niger showed a considerable absorption efficiency in a wide range of temperature, with the maximum biosorption efficiency $(45.5 \%)$ recorded at $37^{\circ} \mathrm{C}[73]$.

Another fungal strain, Phanerochaete chrysosporium, showed a good capacity to reduce the concentration of soluble-exchangeable lead thanks to the following:

(1) the chelation between the fungus and lead by means of active functional groups, such as carboxylic or hydroxyl groups present on the surface of the fungus cell walls,

(2) an enhanced decomposition of organic matter with the consequent augmentation of the humic substances content and capability to immobilize $\mathrm{Pb}$,

(3) an increase in $\mathrm{pH}$ with the resulting reduced solubility of the metal [74].

\subsection{Bioremediation by Bacteria}

The bioremediation treatments with bacteria exploit mechanisms very similar to those already described for fungi. The strategies tackled by bacteria to survive in the presence of heavy metals involve the precipitation of metals as phosphates, carbonates, or sulfides, intracellular accumulation, binding with siderophores, and biosorption on the cell surface or on extracellular polymeric substances [75,76] (Figure 2). Rhodobacter sphaeroides bacterium is capable of changing the speciation of lead by transforming it into inert forms, so making it less bioavailable. This seems to be due to the formation of inert compounds such as lead sulphate $\left(\mathrm{SO}_{4}{ }^{2-}\right.$ present in culture medium) and lead sulfide ( $\mathrm{S}^{2-}$ produced by the bacterium through desulfhydrase) [77].

Teng et al. [78] tried to elucidate the phenomena regulating the lead absorption by Leclercia adecarboxylata. This microorganism reacts to the stress caused by the presence of lead through the production of extracellular polymeric substances (EPS), mainly formed with proteins capable of binding the lead, so keeping lead outside the cell.

Kocuria flava, on the other hand, is able to reduce the bioavailability of lead through its chelation by calcite, which is formed by the large amount of urease, a key enzyme in this process [79].

\subsection{Bioremediation of Organic Lead}

Tetraethyl lead (TEL), triethyl lead (TREL), and trimethyl lead (TRML) are the most common organolead forms, and since the seventies and eighties, various alkyl compounds of lead have been detected in particulates, rainwater, surface waters, sediments, and soils [80]. There is a lack of studies 
on the biological degradation of organolead. Some studies have shown that the degradation of TEL and TRML was mediated by microbial action, following a comparison between the concentration of organolead forms in non-sterile soils and soils subjected to $24 \mathrm{~h}$ of autoclave: degradation occurred much more quickly in non-sterile soils $[81,82]$. However, the degradation mechanisms of TEL and TRML in soil are not well known and microorganisms involved in these processes have not been identified; consequently, there are no techniques available for their bioremediation.

A summary of the considered studies about bioremediation via fungi and bacteria is reported in Table 3.

Table 3. Summary table of studies on the bioremediation of lead via fungi and bacteria.

\begin{tabular}{|c|c|c|c|}
\hline & Study & Species & Mechanism \\
\hline \multirow{5}{*}{ Bioremediation by fungi } & Rhee et al. [69] & $\begin{array}{l}\text { P. javanicus } \\
\text { M. anisopliae }\end{array}$ & $\begin{array}{l}\text { Precipitation of lead as } \\
\text { chloropyromorphite }\end{array}$ \\
\hline & Povedano-Priego et al. [68] & $\begin{array}{c}\text { A. niger } \\
\text { P. chrysogenum } \\
\text { T. viride }\end{array}$ & $\begin{array}{c}\text { Precipitation of lead } \\
\text { phosphate and biosorption }\end{array}$ \\
\hline & Arwidsson et al. [72] & $\begin{array}{l}\text { A. niger } \\
\text { P. bilaiae } \\
\text { P. sp }\end{array}$ & Chelation with LMWOAs \\
\hline & Iram et al. [73] & A. niger & Biosorption \\
\hline & Huang et al. [74] & P. chrysosporium & $\begin{array}{l}\text { Chelation with active } \\
\text { functional groups } \\
\text { Binding with humic } \\
\text { substances, } \\
\text { pH increase, and solubility } \\
\text { reduction }\end{array}$ \\
\hline $\begin{array}{l}\text { Bioremediation by } \\
\text { bacteria }\end{array}$ & $\begin{array}{l}\text { Li et al. [77] } \\
\text { Teng et al. [78] } \\
\text { Achal et al. [79] }\end{array}$ & $\begin{array}{l}\text { R. sphaeroides } \\
\text { L. adecarboxylata } \\
\text { K. flava }\end{array}$ & $\begin{array}{c}\text { Immobilization as inert forms } \\
\text { Binding with EPS } \\
\text { Chelation by calcite }\end{array}$ \\
\hline
\end{tabular}

\section{Bioaugmentation-Assisted Phytoremediation}

Phytoremediation processes can be assisted by fungi and bacteria, so improving the extractive performance of plants and mitigating the main drawback of this remediation strategy, namely, the long application times required to obtain satisfactory results [45-47].

In particular, phytoextraction can be strengthened through the use of microorganisms capable of increasing plant biomass or favoring the metals uptake thanks to the production of enzymes, organic acids, biosurfactants, or siderophores [83]. Braud et al. [84] combined the phytoextraction of cadmium and lead by Zea mays species with the addition of some bacteria capable of producing siderophores, namely Pseudomonas aeruginosa, Pseudomonas fluorescens, and Ralstonia metallidurans. The bacteria were inoculated using different approaches, such as free cells or immobilization in Ca-alginate beads to ensure good survival of microorganisms by reducing the processes of grazing, desiccation, and competition with indigenous bacteria. Furthermore, skim milk was added to enhance the concentration of bacteria in the soil. Lead concentration in maize shoots increased by a factor of 3.4 in the case of free cells and of 3.8 for immobilized cells of $P$. aeruginosa added with skim milk, and a rise of a factor of 3.2 was observed in the case of immobilized cells of $R$. metallidurans supplied with skim milk. The bioaugmentation with free cells of P. fluorescens supplied with skim milk increased the lead concentration in roots, but if we consider the other bacteria at work and inoculation conditions, the bioaugmentation caused a reduction in the amount of $\mathrm{Pb}$ in roots. In general, the inoculation of bacteria induced a decrease in the total uptake of $\mathrm{Pb}$ by maize, but an increase in TF from the roots to the aerial parts. In addition, Braud et al. [84] determined the mobility of lead in the soil by analyzing the first two fractions of the Tessier protocol, and they evidenced an increase in metal mobility caused by the presence of bacteria. This behavior was probably connected to its removal from the interception zone of plant roots and at the same time to an increased translocation of metal from the roots. 
$\mathrm{Li}$ et al. [85] verified the effect of the bioaugmentation of the indigenous fungi Trichoderma asperellum in a soil rich in lead and $\mathrm{Na}^{+}$and $\mathrm{Ca}^{2+}$ ions (high salinity) on the phytoremediation by the Suaeda salsa plant cultivated in flowerpots. The results showed that the chosen plant was able to grow in the contaminated soil and that the bioaugmentation caused an increase in the growth rate and decreased oxidative stress of the plant. Despite this, the BF and TF values below 1 have shown that S. salsa is not particularly efficient in the accumulation of lead and in the translocation of lead from the roots to the aerial parts. Furthermore, bioaugmentation produced a decrease in TF values, i.e., lead remained mainly concentrated in the roots and, therefore, the phytostabilization process prevailed over phytoextraction.

\section{Conclusions}

Lead is a ubiquitous contaminant that poses a danger to human health, and one of the main routes of exposure is the consumption of plant species grown in polluted soils. We have examined several strategies for the recovery of lead-contaminated soils with plants and microorganisms such as fungi and bacteria. The phytoextraction acts mainly by removing heavy metals from the soil, by absorption in the roots or in the aerial parts, whereas the use of bacteria and fungi affects the lead form in the soil, transforming it into more inert and less available forms.

A large variety of plants has been studied for the extraction of lead, and the most promising species seem to be the perennial ones, which avoid annual sowing, and some trees that are able to reach deeper polluted soil layers due to their long roots. However, the main drawback of this approach lies in the long time required to obtain consistent lead reduction and the existence of a maximum concentration limit of pollutant for which this technique is efficient.

The use of bacteria and fungi seems a promising strategy thanks to its ability to precipitate lead into stable forms, so reducing the bioavailability of lead. Although numerous studies have been carried out in the field to assess the potentialities and limits of phytoextraction, the investigations of fungi and bacteria application to restore polluted soils have been limited to a laboratory scale, however, recent research concerning the combined use of microorganisms and phytoremediation have given encouraging results.

Funding: This research was funded by Compagnia di San Paolo (Italy), ReHorti project, grant number CSTO168877. Conflicts of Interest: The authors declare no conflicts of interest.

\section{References}

1. Mahaffey, K.R. Introduction: Advances in Lead Research: Implications for Environmental Health. Environ. Health Perspect. 1990, 89, 3. [CrossRef]

2. European Commission. Directive 2002/95/EC; European Commission: Brussels, Belgium, 2002; pp. $19-23$.

3. Ross, S.M. (Ed.) Toxic Metals in Soil-Plant Systems; Wiley: Chichester, UK, 1994.

4. Tong, S.; von Schirnding, Y.E.; Prapamontol, T. Environmental lead exposure: A public health problem of global dimensions. Bull. World Health Organ. 2000, 78, 1068-1077.

5. Kushwaha, A.; Hans, N.; Kumar, S.; Rani, R. A critical review on speciation, mobilization and toxicity of lead in soil-microbe-plant system and bioremediation strategies. Ecotoxicol. Environ. Saf. 2018, 147, 1035-1045. [CrossRef] [PubMed]

6. Pacyna, E.G.; Pacyna, J.M.; Fudala, J.; Strzelecka-Jastrzab, E.; Hlawiczka, S.; Panasiuk, D.; Nitter, S.; Pregger, T.; Pfeiffer, H.; Friedrich, R. Current and future emissions of selected heavy metals to the atmosphere from anthropogenic sources in Europe. Atmos. Environ. 2007, 41, 8557-8566. [CrossRef]

7. Hettiarachchi, G.M.; Pierzynski, G.M. Soil lead bioavailability and in situ remediation of lead-contaminated soils: A review. Environ. Prog. 2004, 23, 78-93. [CrossRef]

8. Wuana, R.A.; Okieimen, F.E. Heavy Metals in Contaminated Soils: A Review of Sources, Chemistry, Risks and Best Available Strategies for Remediation. ISRN Ecol. 2011, 2011, 1-20. [CrossRef]

9. $\quad$ Lindsay, W.L. Chemical Equilibria in Soils; John Wiley \& Sons: Chichester, UK, 1979. 
10. Nriagu, J.O. Lead orthophosphates-II. Stability of cholopyromophite at $25^{\circ} \mathrm{C}$. Geochim. Cosmochim. Acta 1973, 37, 367-377. [CrossRef]

11. Johnson, F.M. The genetic effects of environmental lead. Mutat. Res./Rev. Mutat. Res. 1998, 410, 123-140. [CrossRef]

12. Casas, J.S.; Sordo, J. Lead: Chemistry, Analytical Aspects, Environmental Impact and Health Effects; Elsevier: Amsterdam, The Netherlands, 2006.

13. Agency for Toxic Substances and Disease Registry (ATSDR). Available online: http://www.atsdr.cdc.gov (accessed on 25 March 2020).

14. Schreck, E.; Foucault, Y.; Sarret, G.; Sobanska, S.; Cecillon, L.; Castrec-Rouelle, M.; Uzu, G.; Dumat, C. Metal and metalloid foliar uptake by various plant species exposed to atmospheric industrial fallout: Mechanisms involved for lead. Sci. Total Environ. 2012, 427-428, 253-262. [CrossRef]

15. Marshall, J.; Corzo, A.; Leigh, R.A.; Sanders, D. Membrane potential-dependent calcium transport in right-side-out plasma membrane vesicles from Zea mays L. roots. Plant J. 1994, 5, 683-694. [CrossRef]

16. Huang, J.W.; Grunes, D.L.; Kochian, L.V. Voltage-dependent Ca2+ influx into right-side-out plasma membrane vesicles isolated from wheat roots: Characterization of a putative Ca2+ channel. Proc. Natl. Acad. Sci. USA 1994, 91, 3473. [CrossRef] [PubMed]

17. Sharma, P.; Dubey, R.S. Lead toxicity in plants. Braz. J. Plant Physiol. 2005, 17, 35-52. [CrossRef]

18. Jaishankar, M.; Tseten, T.; Anbalagan, N.; Mathew, B.B.; Beeregowda, K.N. Toxicity, mechanism and health effects of some heavy metals. Interdiscip. Toxicol. 2014, 7, 60-72. [CrossRef] [PubMed]

19. Abdul Qados, A.M.S. Phytoremediation of $\mathrm{Pb}$ and $\mathrm{Cd}$ by native tree species grown in the Kingdom of Saudi Arabia. Agric. Biol. J. N. Am. 2015, 6, 8-21. [CrossRef]

20. Ribeiro de Souza, S.C.; Adrian Lopez de Andrade, S.; Anjos de Souza, L.; Schiavinato, M.A. Lead tolerance and phytoremediation potential of Brazilian leguminous tree species at the seedling stage. J. Environ. Manag. 2012, 110, 299-307. [CrossRef]

21. McBride, M.B. Arsenic and Lead Uptake by Vegetable Crops Grown on Historically Contaminated Orchard Soils. Appl. Environ. Soil Sci. 2013, 2013, 283472. [CrossRef]

22. Saumel, I.; Kotsyuk, I.; Holscher, M.; Lenkereit, C.; Weber, F.; Kowarik, I. How healthy is urban horticulture in high traffic areas? Trace metal concentrations in vegetable crops from plantings within inner city neighbourhoods in Berlin, Germany. Environ. Pollut. 2012, 165, 124-132. [CrossRef]

23. Finster, M.E.; Gray, K.A.; Binns, H.J. Lead levels of edibles grown in contaminated residential soils: A field survey. Sci. Total Environ. 2004, 320, 245-257. [CrossRef]

24. McBride, M.B.; Shayler, H.A.; Spliethoff, H.M.; Mitchell, R.G.; Marquez-Bravo, L.G.; Ferenz, G.S.; Russell-Anelli, J.M.; Casey, L.; Bachman, S. Concentrations of lead, cadmium and barium in urban garden-grown vegetables: The impact of soil variables. Environ. Pollut. 2014, 194, 254-261. [CrossRef]

25. Weigert, P. Metal loads of food of vegetable origin including mushrooms. In Metals and Their Compounds in the Environment; Merian, E., Ed.; Wiley-VCH: Weinheim, Germany, 1991; pp. 449-468.

26. Sharma, R.K.; Agrawal, M.; Marshall, F. Heavy metal contamination in vegetables grown in wastewater irrigated areas of Varanasi, India. Bull. Environ. Contam. Toxicol. 2006, 77, 312-318. [CrossRef]

27. Lacatusu, R.; Lacatusu, A.-R. Vegetable and fruits quality within heavy metals polluted areas in Romania. Carpathian J. Earth Environ. Sci. 2008, 3, 115-129.

28. Farooq, M.; Anwar, F.; Rashid, U. Appraisal of heavy metal contents in different vegetables grown in the vicinity of an industrial area. Pak. J. Bot. 2008, 40, 2099-2106.

29. Zhu, Y.G.; Chen, S.B.; Yang, J.C. Effects of soil amendments on lead uptake by two vegetable crops from a lead-contaminated soil from Anhui, China. Environ. Int. 2004, 30, 351-356. [CrossRef] [PubMed]

30. Subhashini, V.; Swamy, A.V.V.S. Phytoremediation of $\mathrm{Pb}$ and Ni Contaminated Soils Using Catharanthus roseus (L.). Univers. J. Environ. Res. Technol. 2013, 3, 465-472.

31. Lago-Vila, M.; Arenas-Lago, D.; Rodriguez-Seijo, A.; Andrade, M.L.; Vega, F.A. Ability of Cytisus scoparius for phytoremediation of soils from a $\mathrm{Pb} / \mathrm{Zn}$ mine: Assessment of metal bioavailability and bioaccumulation. J. Environ. Manag. 2019, 235, 152-160. [CrossRef] [PubMed]

32. Ali, H.; Khan, E.; Sajad, M.A. Phytoremediation of heavy metals-concepts and applications. Chemosphere 2013, 91, 869-881. [CrossRef] [PubMed]

33. Ehlken, S.; Kirchner, G. Environmental processes affecting plant root uptake of radioactive trace elements and variability of transfer factor data: A review. J. Environ. Radioact. 2002, 58, 97-112. [CrossRef] 
34. Liu, J.-G.; Qu, P.; Zhang, W.; Dong, Y.; Li, L.; Wang, M.-X. Variations among rice cultivars in subcellular distribution of $\mathrm{Cd}$ : The relationship between translocation and grain accumulation. Environ. Exp. Bot. 2014, 107, 25-31. [CrossRef]

35. Yadav, B.K.; Siebel, M.A.; van Bruggen, J.J.A. Rhizofiltration of a Heavy Metal (Lead) Containing Wastewater Using the Wetland Plant Carex pendula. Clean-Soil Air Water 2011, 39, 467-474. [CrossRef]

36. Baker, A.J.M. Accumulators and excluders -strategies in the response of plants to heavy metals. J. Plant Nutr. 1981, 3, 643-654. [CrossRef]

37. Rotkittikhun, P.; Kruatrachue, M.; Chaiyarat, R.; Ngernsansaruay, C.; Pokethitiyook, P.; Paijitprapaporn, A.; Baker, A.J. Uptake and accumulation of lead by plants from the Bo Ngam lead mine area in Thailand. Environ. Pollut. 2006, 144, 681-688. [CrossRef] [PubMed]

38. Feng, M.H.; Shan, X.Q.; Zhang, S.Z.; Wen, B. Comparison of a rhizosphere-based method with other one-step extraction methods for assessing the bioavailability of soil metals to wheat. Chemosphere 2005, 59, 939-949. [CrossRef] [PubMed]

39. Liu, D.; Islam, E.; Li, T.; Yang, X.; Jin, X.; Mahmood, Q. Comparison of synthetic chelators and low molecular weight organic acids in enhancing phytoextraction of heavy metals by two ecotypes of Sedum alfredii Hance. J. Hazard. Mater. 2008, 153, 114-122. [CrossRef] [PubMed]

40. Bassegio, C.; Campagnolo, M.A.; Schwantes, D.; Goncalves Junior, A.C.; Manfrin, J.; Schiller, A.D.P.; Bassegio, $\mathrm{D}$. Growth and accumulation of $\mathrm{Pb}$ by roots and shoots of Brassica juncea L. Int. J. Phytoremediation 2020, 22, 134-139. [CrossRef] [PubMed]

41. Rahman, F.; Sugawara, K.; Huang, Y.; Chien, M.F.; Inoue, C. Arsenic, lead and cadmium removal potential of Pteris multifida from contaminated water and soil. Int. J. Phytoremediation 2018, 20, 1187-1193. [CrossRef]

42. Huang, Y.; Xi, Y.; Gan, L.; Johnson, D.; Wu, Y.; Ren, D.; Liu, H. Effects of lead and cadmium on photosynthesis in Amaranthus spinosus and assessment of phytoremediation potential. Int. J. Phytoremediation 2019, 21, 1041-1049. [CrossRef]

43. Alaboudi, K.A.; Ahmed, B.; Brodie, G. Phytoremediation of $\mathrm{Pb}$ and $\mathrm{Cd}$ contaminated soils by using sunflower (Helianthus annuus) plant. Ann. Agric. Sci. 2018, 63, 123-127. [CrossRef]

44. Gurajala, H.K.; Cao, X.; Tang, L.; Ramesh, T.M.; Lu, M.; Yang, X. Comparative assessment of Indian mustard (Brassica juncea L.) genotypes for phytoremediation of $\mathrm{Cd}$ and $\mathrm{Pb}$ contaminated soils. Environ. Pollut. 2019, 254, 113085. [CrossRef]

45. Tangahu, B.V.; Sheikh Abdullah, S.R.; Basri, H.; Idris, M.; Anuar, N.; Mukhlisin, M. A Review on Heavy Metals (As, Pb, and Hg) Uptake by Plants through Phytoremediation. Int. J. Chem. Eng. 2011, 2011, 939161. [CrossRef]

46. Mwegoha, W.J.S. The use of phytoremediation technology for abatment soil and groundwater pollution in Tanzania: Opportunities and challenges. J. Sustain. Dev. Afr. 2008, 10, 140-156.

47. Vangronsveld, J.; Herzig, R.; Weyens, N.; Boulet, J.; Adriaensen, K.; Ruttens, A.; Thewys, T.; Vassilev, A.; Meers, E.; Nehnevajova, E.; et al. Phytoremediation of contaminated soils and groundwater: Lessons from the field. Environ. Sci. Pollut. Res. 2009, 16, 765-794. [CrossRef] [PubMed]

48. Tu, S.; Ma, L.Q.; Fayiga, A.O.; Zillioux, E.J. Phytoremediation of arsenic-contaminated groundwater by the arsenic hyperaccumulating fern Pteris vittata L. Int. J. Phytoremediation 2004, 6, 35-47. [CrossRef]

49. Erakhrumen, A.A.; Agbontalor, A. Phytoremediation:an environmentally sound technology for pollution prevention, control and remediation in developing countries. Educ. Res. Rev. 2007, 2, 151-156.

50. Plume Focus Area. Summary Report of a Workshop on Phytoremediation Research Needs; Energy, U.D.O., Ed.; Plume Focus Area: Santa Rosa, CA, USA, 1994.

51. Agency, U.S.E.P. (Ed.) EPA/600/R-99/107: Introduction to Phytoremediation; EPA: Washington, DC, USA, 2002.

52. Ginneken, L.; Meers, E.; Guisson, R.; Ruttens, A.; Elst, K.; Tack, F.; Vangronsveld, J.; Diels, L.; Dejonghe, W. Phytoremediation for heavy metal-contaminated soils combined with bioenergy production. J. Environ. Eng. Landsc. Manag. 2007, 15, 227-236. [CrossRef]

53. Witters, N.; Mendelsohn, R.O.; Van Slycken, S.; Weyens, N.; Schreurs, E.; Meers, E.; Tack, F.; Carleer, R.; Vangronsveld, J. Phytoremediation, a sustainable remediation technology? Conclusions from a case study. I: Energy production and carbon dioxide abatement. Biomass Bioenergy 2012, 39, 454-469. [CrossRef]

54. RECONnet. Tecniche di Fitorimedio Nella Bonifica dei siti Contaminati; Consiglio Nazionale delle Ricerche: Rome, Italy, 2017. 
55. Bridgwater, A.V.; Meier, D.; Radlein, D. An overview of fast pyrolysis of biomass. Org. Geochem. 1999, 30, 1479-1493. [CrossRef]

56. Weiland, P. Biogas production: Current state and perspectives. Appl. Microbiol. Biotechnol. 2010, 85, 849-860. [CrossRef]

57. Mudhoo, A.; Kumar, S. Effects of heavy metals as stress factors on anaerobic digestion processes and biogas production from biomass. Int. J. Environ. Sci. Technol. 2013, 10, 1383-1398. [CrossRef]

58. Willscher, S.; Mirgorodsky, D.; Jablonski, L.; Ollivier, D.; Merten, D.; Büchel, G.; Wittig, J.; Werner, P. Field scale phytoremediation experiments on a heavy metal and uranium contaminated site, and further utilization of the plant residues. Hydrometallurgy 2013, 131-132, 46-53. [CrossRef]

59. Gui, M.M.; Lee, K.T.; Bhatia, S. Feasibility of edible oil vs. non-edible oil vs. waste edible oil as biodiesel feedstock. Energy 2008, 33, 1646-1653. [CrossRef]

60. Angelova, V.; Ivanova, R.; Ivanov, K. Heavy Metal Accumulation and Distribution in Oil Crops. Commun. Soil Sci. Plant Anal. 2011, 35, 2551-2566. [CrossRef]

61. Leung, M. Bioremediation:techniques for cleaning up a mess. J. Biotechnol. 2004, 2, 18-22.

62. Adams, G.O.; Fufeyin, P.T.; Okoro, S.E.; Ehinomen, I. Bioremediation, Biostimulation and Bioaugmention: A Review. Int. J. Environ. Bioremediation Biodegrad. 2015, 3, 28-39. [CrossRef]

63. Margesin, R.; Schinner, F. Bioremediation (natural attenuation and biostimulation) of diesel-oil-contaminated soil in an alpine glacier skiing area. Appl. Environ. Microbiol. 2001, 67, 3127-3133. [CrossRef] [PubMed]

64. Speight, J.G. Removal of Organic Compounds from the Environment. In Environmental Organic Chemistry for Engineers; Butterworth-Heinemann: Oxford, UK, 2017; pp. 387-432. [CrossRef]

65. Haleyur, N.; Shahsavari, E.; Jain, S.S.; Koshlaf, E.; Ravindran, V.B.; Morrison, P.D.; Osborn, A.M.; Ball, A.S. Influence of bioaugmentation and biostimulation on PAH degradation in aged contaminated soils: Response and dynamics of the bacterial community. J. Environ. Manag. 2019, 238, 49-58. [CrossRef] [PubMed]

66. Innemanová, P.; Filipová, A.; Michalíková, K.; Wimmerová, L.; Cajthaml, T. Bioaugmentation of PAH-contaminated soils: A novel procedure for introduction of bacterial degraders into contaminated soil. Ecol. Eng. 2018, 118, 93-96. [CrossRef]

67. Jiang, Y.; Zhang, Z.; Zhang, X. Co-biodegradation of pyrene and other PAHs by the bacterium Acinetobacter johnsonii. Ecotoxicol. Environ. Saf. 2018, 163, 465-470. [CrossRef]

68. Povedano-Priego, C.; Martín-Sánchez, I.; Jroundi, F.; Sánchez-Castro, I.; Merroun, M.L. Fungal biomineralization of lead phosphates on the surface of lead metal. Miner. Eng. 2017, 106, 46-54. [CrossRef]

69. Rhee, Y.J.; Hillier, S.; Gadd, G.M. Lead transformation to pyromorphite by fungi. Curr. Biol. 2012, 22, $237-241$. [CrossRef]

70. Skinner, H.C.W.; Jahren, A.H. Biomineralization. In Treatise on Geochemistry; Holland, H.D., Turekian, K.K., Eds.; Elsevier: Amsterdam, The Netherlands, 2007; Volume 8, pp. 1-69.

71. Ezzouhri, L.; Castro, E.; Moya, M.; Espinola, F.; Lairini, K. Heavy metal_tolerance of_filamentous fungi isolated from polluted sites in Tangier, Marocco. Afr. J. Microbiol. Res. 2009, 3, 35-48.

72. Arwidsson, Z.; Johansson, E.; von Kronhelm, T.; Allard, B.; van Hees, P. Remediation of Metal Contaminated Soil by Organic Metabolites from Fungi I-Production of Organic Acids. Water Air Soil Pollut. 2009, 205, 215-226. [CrossRef]

73. Iram, S.; Shabbir, R.; Zafar, H.; Javaid, M. Biosorption and Bioaccumulation of Copper and Lead by Heavy Metal-Resistant Fungal Isolates. Arab. J. Sci. Eng. 2015, 40, 1867-1873. [CrossRef]

74. Huang, D.L.; Zeng, G.M.; Jiang, X.Y.; Feng, C.L.; Yu, H.Y.; Huang, G.H.; Liu, H.L. Bioremediation of $\mathrm{Pb}$-contaminated soil by incubating with Phanerochaete chrysosporium and straw. J. Hazard. Mater. 2006, 134, 268-276. [CrossRef] [PubMed]

75. Naik, M.M.; Dubey, S.K. Lead resistant bacteria: Lead resistance mechanisms, their applications in lead bioremediation and biomonitoring. Ecotoxicol. Environ. Saf. 2013, 98, 1-7. [CrossRef]

76. Tiquia-Arashiro, S.M. Lead absorption mechanisms in bacteria as strategies for lead bioremediation. Appl. Microbiol. Biotechnol. 2018, 102, 5437-5444. [CrossRef]

77. Li, X.; Peng, W.; Jia, Y.; Lu, L.; Fan, W. Bioremediation of lead contaminated soil with Rhodobacter sphaeroides. Chemosphere 2016, 156, 228-235. [CrossRef] [PubMed]

78. Teng, Z.; Shao, W.; Zhang, K.; Huo, Y.; Zhu, J.; Li, M. Pb biosorption by Leclercia adecarboxylata: Protective and immobilized mechanisms of extracellular polymeric substances. Chem. Eng. J. 2019, 375. [CrossRef] 
79. Achal, V.; Pan, X.; Zhang, D.; Fu, Q. Bioremediation of Pb-contaminated soil based on microbially induced calcite precipitation. J. Microbiol. Biotechnol. 2012, 22, 244-247. [CrossRef]

80. Ou, L.T.; Thomas, J.E.; Jing, T.W. Biological and chemical degradatiom of tetrarthyl lead in soil. Bull. Environ. Contam. Toxicol. 1994, 52. [CrossRef]

81. Teeling, H.; Cypionka, H. Microbial degradation of tetraethyl lead in soil monitored by microcalorimetry. Appl. Microbiol. Biotechnol. 1997, 48, 275-279. [CrossRef]

82. Blais, J.S.; Doige, C.A.; Marshall, W.D.; Knowles, R. Persistence and toxicity of alkyllead salts to anaerobic nitrogen transformations in soil. Arch. Environ. Contam. Toxicol. 1990, 19, 227-234. [CrossRef]

83. Jing, Y.D.; He, Z.L.; Yang, X.E. Role of soil rhizobacteria in phytoremediation of heavy metal contaminated soils. J. Zhejiang Univ.-Sci. B 2007, 8, 192-207. [CrossRef] [PubMed]

84. Braud, A.; Jezequel, K.; Bazot, S.; Lebeau, T. Enhanced phytoextraction of an agricultural Cr- and $\mathrm{Pb}$-contaminated soil by bioaugmentation with siderophore-producing bacteria. Chemosphere 2009, 74, 280-286. [CrossRef] [PubMed]

85. Li, X.; Zhang, X.; Wang, X.; Yang, X.; Cui, Z. Bioaugmentation-assisted phytoremediation of lead and salinity co-contaminated soil by Suaeda salsa and Trichoderma asperellum. Chemosphere 2019, 224, 716-725. [CrossRef]

(C) 2020 by the authors. Licensee MDPI, Basel, Switzerland. This article is an open access article distributed under the terms and conditions of the Creative Commons Attribution (CC BY) license (http://creativecommons.org/licenses/by/4.0/). 